\title{
Proposed Performance Management System for A Project-based Renewable Energy Startup
}

\author{
Sarifah Ulfa Sahubawa and Andika Putra Pratama
}

\section{ABSTRACT}

The number of startups in Indonesia has surpassed 2,000 companies, but only a handful have survived and thrived in the VUCA world. One of the failure causes is the lack of good business management in translating the company's vision and strategy into clear and measurable objectives. For a project-based renewable energy startup, as the current study's focus, it is necessary to focus not only on generating revenue but also on achieving the company's vision and mission to sustain. To address this, we formulated an integrated framework related to the Performance Management System of the renewable energy startup. We combined the Balanced Scorecard as a tool for communicating the company's strategies, Key Performance Indicators as a corporate performance tracking tool, and Objectives and Key Results for a daily basis or short-term goal-setting tool. It is also complemented by the idea of Ethical Climate to embed ethics into the system. Finally, quantifiable company performance measures will be obtained to assist the startup in the decision-making process related to appropriate strategies for corporate sustainability.

Keywords: Balanced Scorecard, Key Performance Indicators, Objectives and Key Results, Performance Management System.

\section{INTRODUCTION}

Startups in Indonesia, despite being relatively new, has grown quite rapidly. The Ministry of Communication and Informatics of the Republic of Indonesia confirmed that Indonesia had 2,193 startups in 2019 [1], and in April 2021, Indonesia has 2,225 startups [2]. However, these numbers have not been followed by the number of startups that have survived and thrived. Startups are notorious for failing during their initial stages of development, typically due to a lack of capital and poor business management. The poor business management includes the founders' inability to identify which resources or areas can contribute to the company's sustainability and to translate the company's vision and strategy into clear and measurable objectives [3].

An Indonesian renewable energy startup experiences the latter problem. As a developing startup, the company has struggled to translate its vision and strategy into concrete goals. The renewable energy startup has been operating for over three years and has six subsidiaries. It has two business units: production units and service units that focus on renewable energy and the environment. The production units produce technology and products to replace the current energy with renewable ones, such as Bio-LNG and biomass power plants; thus, it is under the technology division. Meanwhile, the service units assist in environmental improvements, such as Life Cycle Assessment, under the business division. Despite continued growth, the company's goals have not been fully delivered to the entire team. It
Submitted : August 07, 2021

Published : August 29, 2021

ISSN: $2507-1076$

DOI: $10.24018 /$ ejbmr.2021.6.4.1039

\section{Sarifah Ulfa Sahubawa*}

Bandung Institute of Technology, Bandung, West Java, Indonesia.

(e-mail: sarifah_ulfa@sbm-itb.ac.id)

Andika Putra Pratama

Bandung Institute of Technology,

Bandung, West Java, Indonesia.

(e-mail: andika.putra@sbm-itb.ac.id)

*Corresponding Author leaves unclear directions as each division moves individually.

The unclear direction issue led to other problems. The company is struggling to create performance indicators. Currently, the company used Objectives and Key Results (OKRs) in its performance management. It contains the division leader's targets, which can be changed easily and lack inter-divisional alignment. The malleable OKRs led to an unclear performance appraisal system. Over the three years, the company has only provided two appraisals about the employees' performance of five general points assessed using 360-feedback and people analytics of their working hours. The appraisal still lacks the employee's task performance. In fact, the performance of each employee can describe the company's overall performance. Thereby, the performance appraisal results can assess the company's growth and evaluate and correct any shortcomings. As the company grows, so does the need for a structured and clear performance management system.

The unclear performance appraisal system could also lead to an unclear performance-based compensation and benefit system, affecting employee motivation. The lack of a performance management system could lead to the absence of employee performance control, particularly the underperformers. These effects will be risking the company performance eventually. Hence, this research is aimed to formulate the company's performance management system, starting from helping the company to communicate the company's strategy up to designing the performance appraisal.

This study will use the Balanced Scorecard because it can 
help companies with strategy implementation. The Balanced Scorecard includes a strategy map to help communicate the company's strategies more clearly. This tool can help each division align its goals with the company's goals. Strategic objectives in the Balanced Scorecard can be monitored using Key Performance Indicators to determine whether the company's strategy was successfully implemented. Additionally, this research will employ Objectives and Key Results (OKRs) appropriate for startups and incorporate the Ethical Climate perspective into KPIs to aid in the implementation of strategies that perform better by instilling integrity in the company's human capital.

\section{LITERATURE REVIEW}

\section{A. Performance Management System}

Performance Management System (PMS) is a continuous cycle, consisting of planning, monitoring, and reviewing, that an organization uses to improve both individual and organizational performance by adhering to established strategic objectives [4], [5]. This system ensures that a company's activities, particularly its employees, are effective and efficient. That results are achieved following the business strategy and objectives [5], [6].

It starts with a company strategy that interprets company goals or objectives and key performance dimensions [5], [6]. Following that, during the planning stage, is the identification of required employee activities and targets, performance measures, and indicators via joint goal setting [6], [7]. The monitoring stage assesses the plan's success in achieving the company's goals. Following this, feedback, feedforward, and coaching are required to maximize human capital potential [7]. Continuous and frequent feedback, performance evaluation, and development communications are critical in agile organizations to keep up with changing environments [8].

The review uses the same metrics to assess performance outcomes' goal achievement, which is typically followed by a performance appraisal. The performance evaluation's outcome will be used in determining compensation, financial and non-monetary rewards, promotions, and others [5]-[7]. The results of the performance and goal achievement assessments are also used to set new goals or objectives for the next period. Thus, the entire cycle ensures a more effective performance management system [4], [5].

\section{B. Balanced Scorecard}

Balanced Scorecard is a management tool that businesses can use to carry out their mission and strategy by focusing on financial and non-financial objectives that contribute to financial results [9]. Apart from the Financial perspective, the Balanced Scorecard incorporates three additional perspectives: the Customer, Internal Business Process, and Learning and Growth perspectives, as drivers of the company's financial performance [10]. The Balanced Scorecard is not a tool for strategy development; instead, it is a tool for translating strategy into operational metrics that cascade throughout the organization [9]-[11].

The Balanced Scorecard's critical components are vision, mission, core values, and strategy [10]. Each of the Balanced
Scorecard's essential components is then translated into strategic objectives based on the Balanced Scorecard's four perspectives. Following the objectives formulation, the company establishes Key Performance Indicators for each of these strategic objectives and targets for each indicator. The final stage is to determine the strategic initiatives necessary to accomplish the predetermined goals, detailing the steps taken [10], [11]. The Balanced Scorecard can then be linked to the following performance management methods.

\section{Strategy Map}

The strategy map features the Balanced Scorecard, which describes the cause-and-effect relationship of objectives across the four perspectives in a graphical representation [12]. It shows what to do well in executing the company's strategy [10]. The strategy map can aid in the communication and execution of the business strategy [12]. Private-sector companies typically aim to increase shareholder value by meeting customer needs by improving internal business processes and leveraging intangible assets in learning and growth [12].

The financial perspective includes the company's financial objectives aimed at improving the bottom line, which is related to profitability in two ways: revenue growth and productivity [9], [10], [12]. Based on the customer perspective, the company defines and measures customer and market segments, as well as the value propositions it uses to generate sales and loyalty from targeted customers [9], [10], [13]. Based on the internal business process perspective, the company identifies vital processes that must be carried out correctly to deliver value propositions and meet financial objectives [9], [10]. Lastly, the learning and growth perspective describes the infrastructure that enables its long-term growth and current and future success by describing its intangible assets (human capital, information capital, and organizational capital) [12]. Due to its role as an "enabler" in achieving objectives, this perspective serves as the foundation for subsequent perspectives [10].

\section{Key Performance Indicators}

Key Performance Indicators (KPIs) quantify a business' performance based on its results and serve as a tool for tracking progress toward achieving the business' strategic objectives [4], [14]. KPIs are designed to focus on the critical factors that contribute to a business's success [15]. KPIs are used to monitor both organizational development and performance [16]. Thus, it is critical to choose KPIs that align with the organization's goals and strategies. If there are too many KPIs, it will be difficult for employees to accomplish company goals. The following are some principles relating to KPIs in project management: KPIs must be approved and related to company projects; KPIs show a project's progress toward its goals; The main goal of KPIs is to provide helpful information for decision-making; KPIs can show how close a company is to meet targets, but not how to improve performance; KPIs can help employees see the future [17].

\section{E. Ethical Climate}

Ethical climate is a shared viewpoint about what ethical behaviors should and should not be performed, particularly during decision-making. It is frequently used to resolve ethical dilemmas [18]-[21]. Businesses that successfully 
implement an ethical management style can boost employee engagement, enhancing their competitive advantage and enabling them to thrive [22]. Ethical climate has been linked to work outcomes such as job satisfaction, customer satisfaction, turnover intentions, and job stress [18], [19], [23].

This study will insert the Ethical Climate perspective to monitor ethics and obtain desired outcomes based on those outcomes. The Ethical Climate is frequently measured using the Ethical Climate Questionnaire (ECQ), which consists of numerous statements representing nine Ethical Climate types [21]. The respondent will select the statements that best match their responses on a 6-point Likert scale. The nine Ethical Climate types are self-interest, company profit, efficiency, friendship, teamwork, social responsibility, personal morality, company rules and procedures, and laws and professional codes [21].

\section{F. Objectives and Key Results}

Startup companies frequently use Objectives and Key Results (OKRs) to set goals to collaborate on setting and achieving goals [24]. OKRs are ideal for today's fast-paced world due to their simplicity and adaptability [24], [25]. There are two parts of the OKRs: Objectives and Key Results. Objectives describe "what" the company wants to achieve, while Key Results describe "how" the company will achieve it [24]. Typically, the Objectives are ambitious, actionoriented, concrete, and inspiring, while the Key Results are measurable, specific, challenging but still achievable, and time-bound [24].

An Objective can be met by supplementing two to five Key Results that combined quantitative and qualitative elements where OKRs typically for a short period, such as quarterly [24], [25]. OKRs are established transparently, with all employees aware of the OKRs assigned to each division within the company. Hence, each employee can easily create and update their OKRs without waiting for top-down cascading to achieve a healthy balance of autonomy and alignment [24], [25]. OKRs are compatible with continuous performance management, including a Conversations, Feedback, and Recognition (CFR) tool that many startups use [24].

OKRs can perform the same functions as the Balanced Scorecard and KPIs, i.e., setting goals and measuring performance. The distinction is that Balance Scorecard is used to communicate the company's cause-effect objectives, while KPIs are used to track objectives' performance, and OKRs are best used for short-term goal setting. Additionally, cascaded Balance Scorecard objectives and KPIs place an emphasize on alignment, whereas OKRs place an emphasize on agility and autonomy [25].

\section{G. Performance Appraisal}

The final stage of the performance management system is performance appraisal. The company measures how well employees perform in their roles compared to their expectations [4], [6]. Employee development and administrative decisions (promotion, demotion, and others) can use this performance appraisal. Furthermore, performance appraisal measures the effectiveness and efficiency of a company's employees [26].

Performance assessments can be formal or informal; informal evaluations can occur in the form of feedback. By contrast, formal assessment is typically conducted through an annual performance review. Formal performance evaluations can take two forms: attribute-based evaluations (graphic rating scales and mixed-standard scales) and narrative assessments [6]. Typically, the company will combine several approaches to produce the most objective assessment possible. Generally, managers or superiors, coworkers, subordinates, self, and outsiders (e.g., customers) can provide information about the performance. The performance appraisal can use the 360-degree method that uses all the positions mentioned earlier as appraisers and aims to minimize assessment bias [6], [27].

\section{RESEARCH METHODOLOGY}

Based on the literature reviews, the research framework used in this research is shown in Fig. 1. which incorporates all the tools in developing the performance management system for the renewable energy startup. The research method used in this study is a mixed-method that combines qualitative and quantitative methods. The qualitative methods are in interviews and discussions with the key leaders to identify the business issue, its strategic objectives, and initiatives, KPIs, and its priorities and targets. The key leaders are the CEO, CTO, CBO, and Human Capital Manager, who led the three main divisions in the company, i.e., Business, Technology, and Human Capital divisions. In contrast, the quantitative method is used in a questionnaire to assess the company's need for the Balanced Scorecard. The required data include the company's vision, mission, and values, and job descriptions.

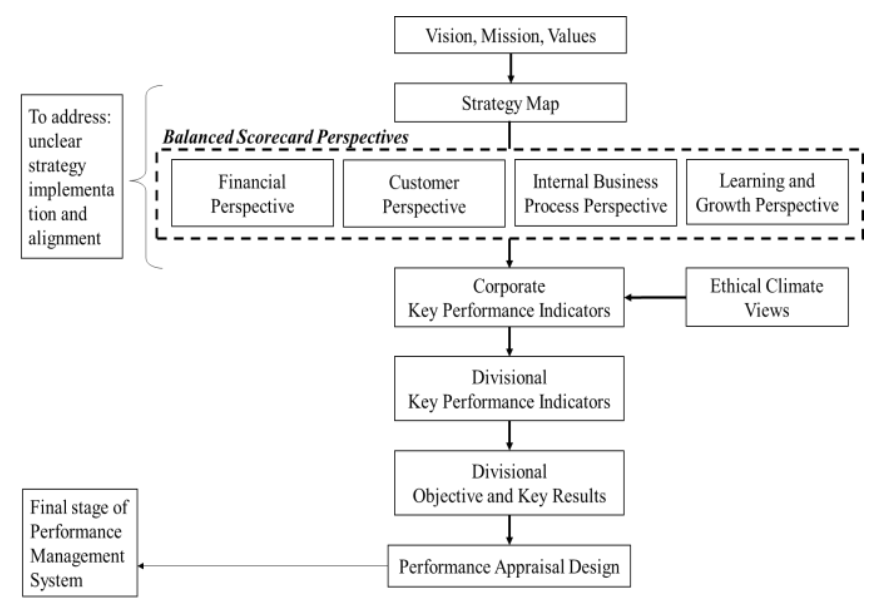

Fig. 1. Research framework.

\section{RESEARCH FINDINGS}

\section{A. Current Performance Management System}

According to the interviews with the Human Capital Manager and CEO, the company has thus far only performed the monitoring stage. In comparison, neither the planning nor the reviewing stages have been systematically conducted. The first issue is the lack of a clear upper management direction. Each division moves according to the leader's goals, the situation, and needs. The lack of alignment and inter-divisional relationships can hinder the company's 
progress towards its strategic goals.

In addition, there is an unstructured OKR documentation. Due to a lack of clear direction from upper management, the OKR can be easily changed. This issue prevents the company from creating a structured Performance Appraisal where the previous project's work is documented even though the new project is underway. So, with clear communication about the company's goals, the OKR formed should be more structured, transparent, and aligned with the company's goals.

The company does not have an exact schedule for providing performance appraisals. A performance appraisal is usually done at the end of a management cycle or twice a year. Without a structured schedule, employees are not evaluated on their progress and contribution to the company. The next issue is about the content of the appraisal. Employees have received performance evaluations of accountability, communication, leadership, problem-solving, and teamwork aspects and people analytics reports in their appraisals, accompanied by a written assessment. This evaluation is still incomplete because it does not assess employee performance in terms of tasks.

Besides the problems mentioned earlier, some things can be reused in developing its performance management system. The first thing is that the performance evaluations use a 360degree feedback system from leaders and peers. The company also has implemented weekly one-on-one sessions and direct coaching as a form of performance monitoring as continuous performance management. The one-on-one sessions provide feedback based on their working log data (an online spreadsheet containing OKR, percentage progress or activity completion, and weekly workload perceptions). The employee fills out this dashboard, which is visible to the leader and Human Capital Manager. The employee can update the data, and the leader can use it to track team performance.

\section{B. Company's Need for A Balanced Scorecard}

A questionnaire is conducted to determine whether the company can use the Balanced Scorecard, which contains twenty statements using a Likert scale of one to five to indicate the level of agreement [10]. The respondents are the four key leaders who play an essential role in formulating and implementing the company's strategy.

The score obtained from the respondents is 69.5 , indicating that the company is having difficulty executing its strategy; hence the Balanced Scorecard is strongly recommended. In addition, the company has never used a tool to communicate its strategy. Besides its usefulness, its simplicity for startup companies makes the Balanced Scorecard suitable for resolving its problem.

\section{Analysis of Vision, Mission, and Values}

A company's vision, mission, values, and strategy are required for a balanced scorecard. Values communicate the company's guiding principles, vision communicates the company's future, while mission communicates the reason to exist. Strategies infuse values into daily business operations to achieve the vision and mission [10]. The company currently has three elements, i.e., vision, mission, and values which need to be translated into strategic objectives. These strategic objectives will be used in developing the strategy map. The strategic objectives obtained are as follows: innovation excellence, operational excellence, sustainable partnership, and exceptional human capital.

\section{Objectives of Each Division}

The previous strategic objectives need to be supplemented and reviewed with strategies currently implemented by the company's divisions - each division's objectives obtained through interviews with each leader. The interviews will obtain their strategic initiatives grouped into common strategic objectives using the Balanced Scorecard perspective to demonstrate that these divisions or position's objectives are aligned. The strategic objectives obtained through interviews are shown in Table I.

TABLE I: THE STRATEGIC OBJECTIVES OBTAINED THROUGH INTERVIEWS

\begin{tabular}{|c|c|c|}
\hline $\begin{array}{c}\text { Balanced } \\
\text { Scorecard } \\
\text { Perspective }\end{array}$ & Strategic Objectives & Unit / Person in Charge \\
\hline Financial & $\begin{array}{l}\text { 1. Increase revenue } \\
\text { 2. Improve cost structure }\end{array}$ & $\begin{array}{l}\text { 1. CEO, Technology, Business } \\
\text { 2. Technology, Business, } \\
\text { Human Capital }\end{array}$ \\
\hline Customer & $\begin{array}{l}\text { 1. Increase the number of } \\
\text { customers } \\
\text { 2. Maintain the number } \\
\text { of customers } \\
\text { 3. Prioritize superior } \\
\text { product/service quality }\end{array}$ & $\begin{array}{l}\text { 1. CEO, Technology, Business } \\
\text { 2. CEO } \\
\text { 3. CEO, Technology, Business }\end{array}$ \\
\hline $\begin{array}{l}\text { Internal } \\
\text { Business } \\
\text { Process }\end{array}$ & $\begin{array}{l}\text { 1. Ensure operational } \\
\text { excellence } \\
\text { 2. Ensure operational } \\
\text { continuity }\end{array}$ & $\begin{array}{l}\text { 1. Technology, Business } \\
\text { 2. CEO, Technology, Business }\end{array}$ \\
\hline $\begin{array}{l}\text { Learning } \\
\text { and Growth }\end{array}$ & $\begin{array}{l}\text { 1. Grow the best people } \\
\text { 2. Retain the best people } \\
\text { 3. Attract the best people } \\
\text { 4. Nurture innovation } \\
\text { culture }\end{array}$ & $\begin{array}{l}\text { 1. CEO, Technology, Business, } \\
\text { Human Capital } \\
\text { 2. CEO, Technology, Business, } \\
\text { Human Capital } \\
\text { 3. Human Capital } \\
\text { 4. CEO, Technology, Business, } \\
\text { Human Capital }\end{array}$ \\
\hline
\end{tabular}

\section{DISCUSSION}

\section{A. Alignment of Strategic Objectives Obtained}

The alignment of objectives derived from the company's vision, mission, and values and interviews is shown in Fig. 2. Some objectives are not explicitly stated in the vision, mission, or values, but can be found in the Balanced Scorecard's interview results, i.e., financial objectives. Both sources practically complement one another. Based on the objectives obtained, it is clear that there is still alignment between divisional activities and the company's strategic objectives.

These strategic objectives will be communicated to all employees effectively using the strategy map, which will be discussed later. Additionally, the targets and measures will be determined and used in the performance appraisal. Thereby, the company's performance appraisal will also be equipped with the employee's task performance.

\section{B. Proposed Strategy Map}

The strategy map shows the relationship between objectives and perspectives. Thus, the employee can ascertain the relationship between objectives necessary to accomplish the company's vision. The company can also improve 
performance in unfavorable areas and other goals that affect those areas. The strategic objectives based on the company's vision, mission, and values complement the financial objectives obtained through the interviews in a strategy map, shown in Fig. 3. Additionally, increased revenue and cost savings can result in profitability for the business [12]; thus, the increased profitability is included in the strategy map.

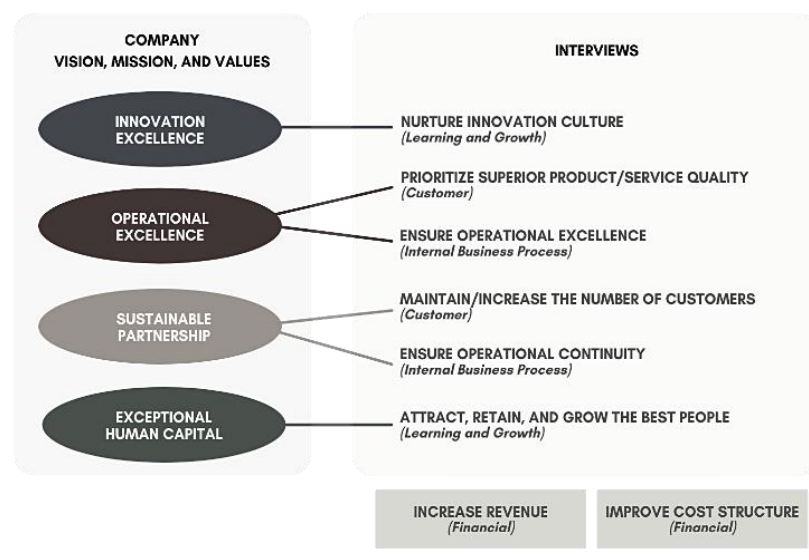

Fig. 2. Strategic objectives alignment.

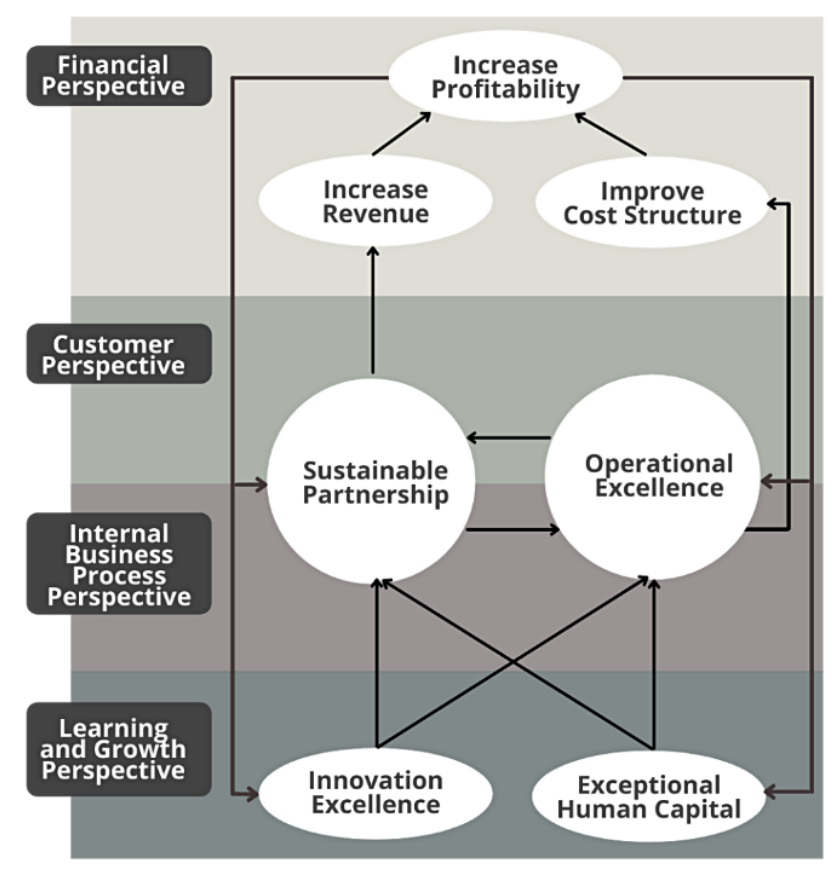

Fig. 3. Strategy map based on the company's vision, mission, and values.

Furthermore, Fig. 3. depicts a feedback loop between increased profitability and strategic objectives in the underlying perspective. This feedback is a way for the business to invest in its systems and human capital [9]. Additionally, it adheres to stakeholder theory, which states that stakeholders should not have their interests and benefits prioritized over those of another; thus, arrows connecting the firm and its stakeholder's constituents are bidirectional [28]. It means that profitability enables the accomplishment of other strategic objectives to ensure the company's sustainability.

A more precise explanation of each strategic objective based on the key leaders' current strategy is shown in Fig. 4. The two learning and growth objectives impact the overall internal business process objectives. The company's business processes, and company growth are built on exceptional people and a culture of innovation. Whereas in the internal business process perspective, ensuring operational continuity affects operational excellence due to the need of third parties in securing the company's supply chain. Meanwhile, ensuring operational excellence will impact the customer and financial perspectives. Ensuring operational excellence aims to continuously improve business processes that help the company provide better service and product quality to customers. Thus, these objective impacts prioritize superior product/service quality from the customer perspective.

The products' and services' quality will affect the number of customers. Superior quality will undoubtedly increase customer satisfaction, allowing the company to retain existing customers. Additionally, this superior quality can help the renewable energy startup project a positive image to its customers and potential customers. It may indirectly increase future customer numbers, mainly if positive wordof-mouth from satisfied customers is adequate. This increase in customer numbers will have a financial impact on the revenue objective.

The renewable energy startup's revenue will increase as the number of customers increases through the initiatives taken. An additional strategic objective in the financial perspective is to optimize the cost structure, which relates to the company's cost-cutting efforts. Increased profitability can support the company's ability to continue innovating, as the ideation process also involves significant research and development cost; thereby, it assists innovation and operational excellence. Additionally, the profits help the company to improve quality control of products and services delivered to customers. Increased profits can also help the company achieve the exceptional human capital objective by improving employee welfare. For instance, loyal employees equipped with qualified competencies can adequately deliver the company's services and products, which undoubtedly affects customer satisfaction; consequently, increasing the number of customers increases the company's revenue further. Thus, profitability contributes to the company's sustainability.

\section{Proposed Key Performance Indicators}

The proposed Key Performance Indicators were created based on the strategic objectives in the previous strategy map. The key leaders have approved the KPIs and their targets. The KPIs are then measured using their respective weight based on the priority ranking obtained from the key leaders' perspectives using the Analytical Hierarchy Process Priority Calculator in https://bpmsg.com/ahp/ahp-calc.php. The weight of each KPI will be used in the performance appraisal to assess the employee's performance. The proposed KPIs are listed in Table II.

\section{Ethical Climate Views on Strategic Objectives}

Positive outcomes, such as job satisfaction, have been demonstrated for an ethical climate, which can assist the business in achieving its objectives. Integrating ethics and the strategy aims to keep a business on track strategically, resulting in a sustainable competitive advantage and enabling it to create and share value with stakeholders acceptably and fairly [29]. The inclusion of ethical perspectives is expected to increase desirable workplace behaviors such as cultivating 
a shared belief that organizational interests come first and encouraging employees to act honestly and transparently [18].

B ased on the KPI's weight previously, it is known that the renewable energy startup's current primary focus is on financial objectives, which can be harmful to the company if heavily focused on financial performance. Ethical views are required to control the company's actions, particularly toward the outside of the company. Self-interest climate, for example, should not be the dominant ethical climate in a company. In addition, heightened conflicts were positively associated with the egoistic climate [23]. It occurs when some or all of the company is more focused on personal and company interests than on other concerns, such as teamwork, social responsibility, and rules or procedures.
The ethical climate can help the company's image. Customers admire a business that is perceived as ethical. Employees are also expected to work in an ethical environment [22]. Thereby, adding ethical climate views can complement the company's strategic goals. While the ethical climate is not a priority for the company at the moment, that does not mean it is unimportant to address. This section will define the ethical climate types concerning the previously mentioned objectives listed in Table III. These ethical climate types then are inserted as KPIs, shown in Table IV.

The caring climate's target is five because the renewable energy startup is built on collaboration to generate innovations for their development. In contrast, the rest of the climate types' KPIs aim for four. These KPIs are fully responsible for all parts of the company to increase awareness of the ethical climate.

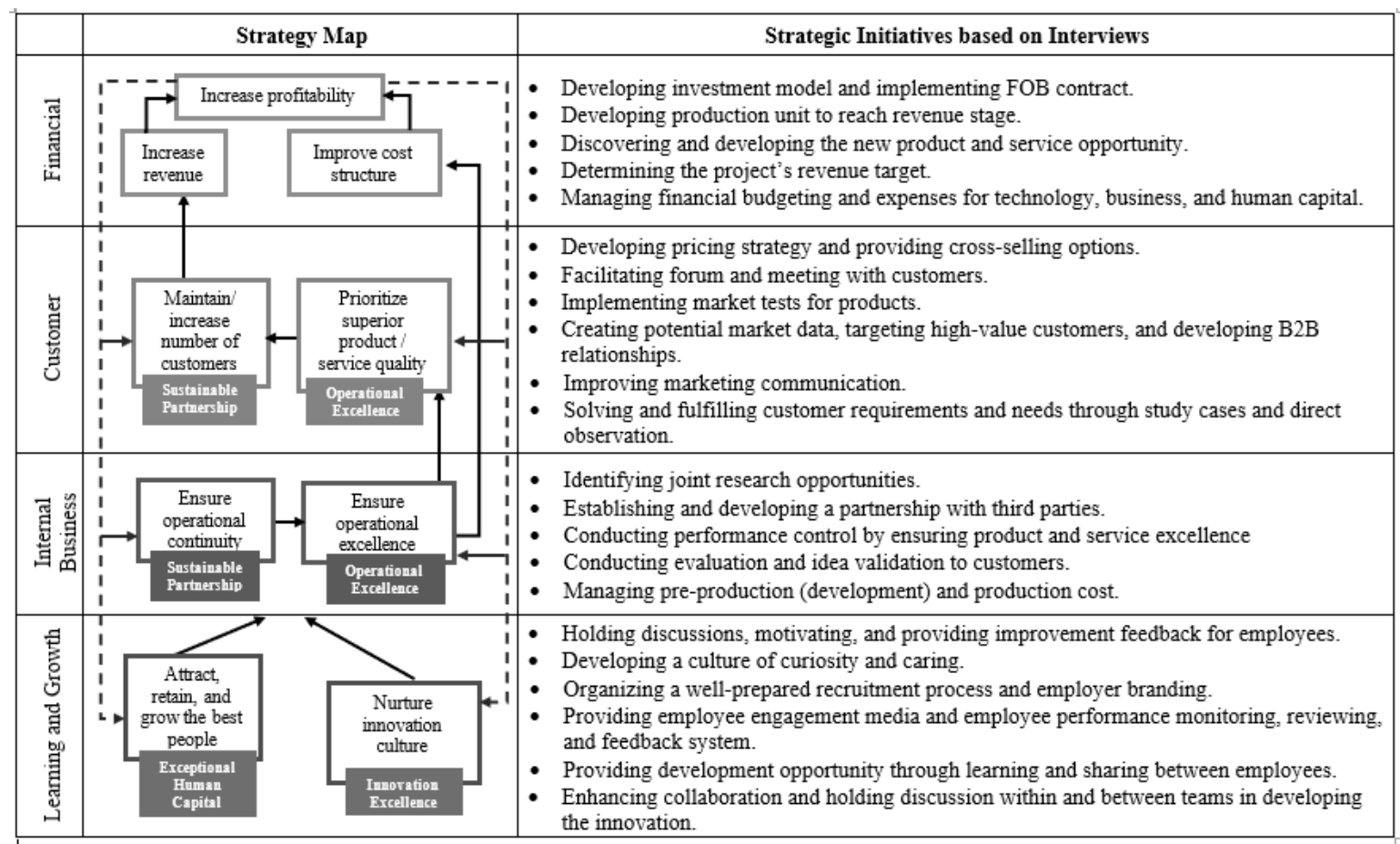

Fig. 4. Strategy map based on existing strategies.

TABLE II. THE PROPOSED KEY PERFORMANCE INDICATORS

\begin{tabular}{|c|c|c|c|c|}
\hline $\begin{array}{c}\text { Balanced Scorecard } \\
\text { Perspective }\end{array}$ & Strategic Objectives & KPI & Target & Weight \\
\hline \multirow{3}{*}{ Financial } & 1. Increase revenue & 1. Revenue growth & 1. $20 \%$ & $1.25 .2 \%$ \\
\hline & 2. Improve cost structure & 2. COGS & 2. N/A & 2. $13.9 \%$ \\
\hline & 3. Increase profitability & 3. Net income & 3. N/A & 3. $7.6 \%$ \\
\hline Customer & $\begin{array}{l}\text { 1. Sustainable partnership: } \\
\text { Maintain/Increase the number } \\
\text { of customers } \\
\text { 2. Operational excellence: } \\
\text { Prioritize superior } \\
\text { product/service quality }\end{array}$ & $\begin{array}{l}\text { 1. A. Repeat purchase rate } \\
\text { B. Customer growth } \\
\text { C. Number of new followers on social media } \\
\text { 2. A. Number of complaints } \\
\text { B. Customer satisfaction index }\end{array}$ & $\begin{array}{l}\text { 1. A. } 80 \% \\
\text { B. } 30 \% \\
\text { C. } 67 \% \\
\text { 2. A. } 10 \% \\
\text { B. } 4 \text { ("satisfied") }\end{array}$ & $\begin{array}{l}\text { 1. A. } 1.0 \% \\
\text { B. } 1.8 \% \\
\text { C. } 3.1 \% \\
\text { 2. A. } 0.7 \% \\
\text { B. } 3.1 \%\end{array}$ \\
\hline \multirow{5}{*}{$\begin{array}{l}\text { Internal Business } \\
\text { Process }\end{array}$} & \multirow{5}{*}{$\begin{array}{l}\text { 1. Operational excellence: } \\
\text { Ensure operational excellence } \\
\text { 2. Sustainable partnership: } \\
\text { Ensure operational continuity }\end{array}$} & 1. A. Production: time efficiency & 1. A. $95 \%$ & 1. A. $1.6 \%$ \\
\hline & & B. Number of failures & B. 0 & B. $4.0 \%$ \\
\hline & & C. Service: response time & C. 7 & C. $6.1 \%$ \\
\hline & & D. $R \& D$ expense & D. $1 \%$ & D. $2.6 \%$ \\
\hline & & 2. A. On-time delivery & 2. A. $100 \%$ & 2. A. $0.7 \%$ \\
\hline \multirow{6}{*}{$\begin{array}{l}\text { Learning and } \\
\text { Growth }\end{array}$} & \multirow{6}{*}{$\begin{array}{l}\text { 1. Exceptional human capital } \\
\text { 2. Innovation excellence }\end{array}$} & 1. A. Candidate experience rating & 1. A. 4 ("satisfied") & 1. A. $1.2 \%$ \\
\hline & & B. Employee satisfaction rating & B. 4 ("satisfied") & B. $4.4 \%$ \\
\hline & & C. Employee turnover rate & C. $15 \%$ & C. $1.8 \%$ \\
\hline & & D. Number of training & D. 24 & D. $2.8 \%$ \\
\hline & & E. Number of conducted one-on-one sessions & E. $50 \%$ & E. $6.9 \%$ \\
\hline & & 2. Number of employees with new ideas & 2. $90 \%$ & 2. $10.6 \%$ \\
\hline
\end{tabular}


European Journal of Business and Management Research www.ejbmr.org

TABLE III. EThicAl Climate Views ON STRATEGic OBJectives

\begin{tabular}{|c|c|c|}
\hline Strategic Objective & Ethical Climate Type & Explanation \\
\hline Increase revenue & Company profit & $\begin{array}{l}\text { This type focuses on the organization's concerns [21] or the company has self-interest in } \\
\text { the broad scope of the company. }\end{array}$ \\
\hline $\begin{array}{l}\text { Improve cost } \\
\text { structure }\end{array}$ & Efficiency & $\begin{array}{l}\text { This type focuses on more significant social or economic systems' concerns [21] related to } \\
\text { the efficiency of both costs and resources owned by the company. }\end{array}$ \\
\hline $\begin{array}{l}\text { Sustainable } \\
\text { partnership }\end{array}$ & Social responsibility & $\begin{array}{l}\text { This climate focuses on considering elements outside the company [21]. This objective is } \\
\text { related to customer satisfaction and partnerships with third parties. The initiatives sought } \\
\text { to maintain the relationship between the company and its partners. }\end{array}$ \\
\hline $\begin{array}{l}\text { Operational } \\
\text { excellence }\end{array}$ & Company rules and procedures & $\begin{array}{l}\text { This type comes from within the company [21] that relates to the company's efforts to } \\
\text { improve the existing system; thus, the employees must obey the company's rules. }\end{array}$ \\
\hline $\begin{array}{l}\text { Exceptional human } \\
\text { capital }\end{array}$ & $\begin{array}{l}\text { 1. Caring: Team interest, } \\
\text { Friendship, Social } \\
\text { responsibility, and Efficiency } \\
\text { 2. Law and professional codes }\end{array}$ & $\begin{array}{l}\text { 1. Retain the best people is related to employee satisfaction that keeps them in the } \\
\text { company. The caring climates positively affect overall job satisfaction [23]. } \\
\text { 2. The combination of social responsibility and law and professional codes affects } \\
\text { employee engagement and satisfaction by using knowledge management on job } \\
\text { performance employees [23]. Knowledge management is related to competencies. }\end{array}$ \\
\hline $\begin{array}{l}\text { Innovation } \\
\text { excellence }\end{array}$ & $\begin{array}{l}\text { Benevolent: Friendship, Team } \\
\text { interest, and Social responsibility }\end{array}$ & $\begin{array}{l}\text { Benevolent climates positively increase risk-taking propensity related to innovation efforts } \\
\text { [23] }\end{array}$ \\
\hline
\end{tabular}

TABLE IV. PRoposed KPIs FOR THE ETHICAL Climate PeRsPective

\begin{tabular}{lcc}
\hline \hline \multicolumn{1}{c}{ KPI } & Formula & Target \\
\hline ECQ score: Caring climate & Average Likert & 5 \\
ECQ score: Company profit & scale 1-6 in Ethical & 4 \\
ECQ score: Company rules and procedures & Climate & 4 \\
ECQ score: Laws and professional codes & Questionnaire & 4 \\
\hline \hline
\end{tabular}

\section{E. Proposed Objectives for Objectives and Key Results}

The Business and Technology divisions have teams under them, which do not have a team leader; thus, the teams are directly supervised by the respective leader, i.e., CBO and CTO. The leader's KR can be directly translated into an objective for the teams that report to him [24]. The proposed objectives for OKRs in this section are only for the leaders, i.e., CEO, CTO, CBO, and Human Capital Manager, and based on current strategic initiatives, which are listed in Table V. The previous strategic initiatives consist of the leader's personal and the team's actions. Thereby, the job descriptions explaining each team's responsibilities are required to group objectives for each OKR.

The formulation of main objectives uses the top ten-ranked KPIs' initiatives to maintain the company's focus. Defining Key Results is a collaborative process between the leader and his team and advocates autonomy. Moreover, this collaborative process empowers employees to contribute to the company's growth. The average percentage of KRs achieved in the relevant objective determines the respective objective assessment. The KR measurement ranges from 0 to 1, with 1 representing a successful KR [24].

\begin{tabular}{|c|c|}
\hline Position & Proposed Objectives for OKRs \\
\hline CEO & $\begin{array}{l}\text { 1. Increase revenue from the production sector. } \\
\text { 2. Grow the people. } \\
\text { 3. Hold customers meetings. }\end{array}$ \\
\hline $\mathrm{CBO}$ & $\begin{array}{l}\text { 1. Minimize division's expenses } \\
\text { 2. Achieve the project's revenue target of IDR X. } \\
\text { 3. Facilitate innovation culture and continuous feedback }\end{array}$ \\
\hline CTO & $\begin{array}{l}\text { 1. Minimize division's expenses } \\
\text { 2. Improve production sector and internal experiences }\end{array}$ \\
\hline Human Capital & 1. Minimize division's expenses \\
\hline Manager & 2. Improve employees' learning and experience \\
\hline
\end{tabular}

\section{F. Proposed Performance Appraisal Design}

The performance appraisal will use a quantitative method to compare employee work results based on the strategic objectives. Calculations will be made by comparing actuals to targets for each KPI. This design will complement the company's existing performance appraisal, including people analytics and previous five points assessments. The appraisers used is leader, peer, and subordinate (360assessment) with proportions shown in Table VI. At the same time, the performance appraisal period is once a year.

The first part of the performance appraisal is the business strategic objectives that will assess KPIs under the appraisee's position towards their realization and obtain a score of accomplishments. It will be supplemented by nonweighted ethical climate KPIs. The achievement of the ethical climate KPIs will examine the company's climates.

The second part is the personal OKRs. Each objective's score is the average of the key results. In this case, all quarterly OKRs and project-based OKRs are recorded, and the average quarterly and project-based objective score is calculated as a percentage. The appraisee's performance is graded based on the final score according to the grading identification shown in Table VII. The grades used are from the literature, whereas the score is based on the Human Capital Manager aspiration. The final part is reusing the previous performance appraisal in the company. In comparison to before (using the Likert scale without explanations), the difference now lies in the use of an additional appraiser who is a subordinate and the use of the grading identification explained in Table VII.

TABLE VI. THE APPRAISER'S PROPORTION

\begin{tabular}{|c|c|c|c|c|}
\hline \multirow{2}{*}{\multicolumn{2}{|c|}{ Position }} & \multicolumn{3}{|c|}{ Appraiser } \\
\hline & & Leader & Peer & Subordinate \\
\hline \multicolumn{2}{|c|}{ CTO, CBO, HC Manager } & $50 \%$ & $25 \%$ & $25 \%$ \\
\hline \multicolumn{2}{|c|}{ Staff } & $67 \%$ & $33 \%$ & - \\
\hline \multicolumn{2}{|c|}{ CEO } & - & - & $100 \%$ \\
\hline \multicolumn{5}{|c|}{ TABLE VII. GRADING IDENTIFICATION } \\
\hline Grade & \multicolumn{3}{|c|}{ Explanation [4] } & Score \\
\hline $\begin{array}{l}\text { Very effective } \\
\text { (A) }\end{array}$ & \multicolumn{3}{|c|}{$\begin{array}{l}\text { Exceeds required standards, } \\
\text { consistently outperforms } \\
\text { expectations, and achieves all goals. }\end{array}$} & $\geq 100 \%$ \\
\hline Effective (B) & \multicolumn{3}{|c|}{$\begin{array}{l}\text { Meets required standards, } \\
\text { expectations, and goals. }\end{array}$} & $75 \%-99 \%$ \\
\hline Developing (C) & \multicolumn{3}{|c|}{$\begin{array}{l}\text { Meets most objectives but could be } \\
\text { improved }\end{array}$} & $50 \%-74 \%$ \\
\hline Improvable (D) & \multicolumn{3}{|c|}{$\begin{array}{l}\text { Achievements fall short of } \\
\text { expectations and must be } \\
\text { significantly improved }\end{array}$} & $\leq 49 \%$ \\
\hline
\end{tabular}




\section{G. Proposed Performance Management System}

The proposed performance management system combines the performance management cycle [4] and the typical OKR cycle [24] while considering the performance management system implemented at the renewable energy startup. The performance management cycle is shown in Fig. 5. The first stage is planning, starting with creating strategic objectives and developing a strategy map and related KPIs. In this stage, the company can also update the job descriptions and job profiles. After that, the company socializes the company's strategy map and its KPIs and targets. Typically, four to six weeks before the first quarter begins, the leaders and teams formulate their strategic initiatives to develop into the team's OKRs. Once the quarter starts, the teams communicate their
OKRs to the company, and the employees share their OKRs in the following week according to the team's OKRs [24].

Then, the second stage (i.e., monitoring) starts. At this stage, the company conducts weekly one-on-one sessions and simultaneously implement CFRs in two-way communications. The company should provide trainings or learning activities during this stage to improve the employees' performance and competencies. The company will review and score the OKRs performance a week before the quarter ends [24]. At the last stage (i.e., reviewing), the company holds a performance appraisal to assess the annual employee's performance, including all four quarterly OKRs. The company also reviews the overall performance management system during the previous one-year period to improve the next cycle.

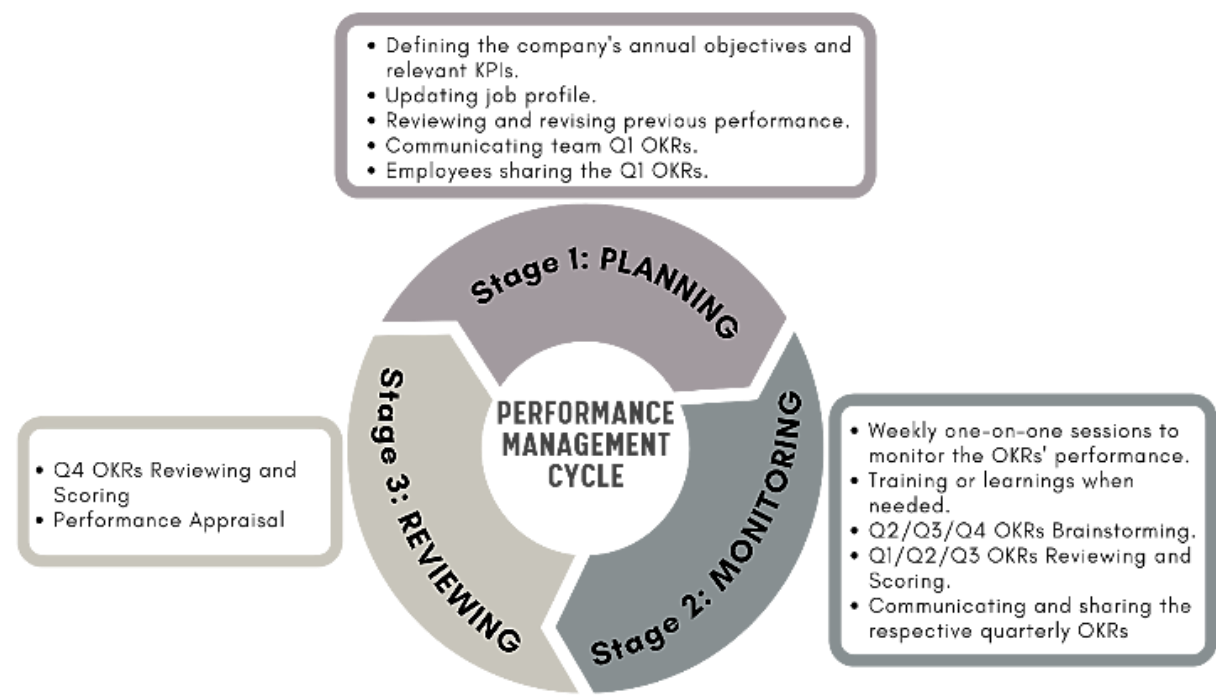

Fig. 5. Proposed performance management cycle.

\section{CONCLUSION}

This research aims to propose a performance management system for a project-based renewable energy startup. The performance management system combines the Balanced Scorecard, Key Performance Indicators, and Objectives and Key Results, as well as Ethical Climate. The combination encourages the company's agility by using OKRs and simultaneously provide clear communication of the strategy to the whole company. The term "agile" might sometimes make the company tend to respond to the circumstances and not pay attention to its goals that can hinder its development. This research is expected to help the startup company maintain its strategic directions while promoting its agility and monitoring its performance and awareness of ethical behaviors.

\section{REFERENCES}

[1] KOMPAS.com, "Menkominfo Pamerkan Pesatnya Perkembangan Startup Indonesia," 2020 https://kominfo.go.id/content/detail/23975/di-wef-2020menkominfo-pamerkan-pesatnya-perkembangan-startupindonesia/0/sorotan_media (accessed Apr. 10, 2021).

[2] S. "Countries," https://www.startupranking.com/countries (accessed Apr. 10, 2021).

[3] C. Llorach and E. Ottoson, "The Balanced Scorecard during the Early Stages of a Tech Firm - A Multiple Case Study Regarding
Performance Management in Swedish Tech Startups," Uppsala University, 2016.

[4] M. Armstrong, Armstrong's Handbook of Performance Management: An Evidence-based Guide to Delivering High Performance, Sixth. New York: Kogan Page, 2017.

[5] B. Kaviya and C. Hema, "Performance Management in Construction," Int. J. Innov. Res. Sci. Eng. Technol., vol. 4, no. 4, pp. 2093-2100, 2015, doi: 10.15680/IJIRSET.2015.0404124.

[6] R. A. Noe, J. R. Hollenbeck, B. Gerhart, and P. M. Wright, Human Resource Management: Gaining A Competitive Advantage, 10th ed. New York: McGraw-Hill Education, 2017.

[7] B. Patel, A. Patel, and A. Sharma, "Examining the Role of HR Professionals in Developing Efficient and Effective Performance Management Systems," AAYAM, vol. 10, no. 1, pp. 17-24, 2020.

[8] L. Darino, M. Sieberer, A. Vos, and O. Williams, "Performance Management in Agile Organizations," New York, 2019. [Online]. Available: $\quad$ https://www.mckinsey.com/businessfunctions/organization/our-insights/performance-management-inagile-organizations.

[9] R. S. Kaplan and D. P. Norton, "The Balanced Scorecard: Translating Strategy into Action." President and Fellows of Harvard College, USA, pp. 1-329, 1996, [Online]. Available: https://bok.asia/book.

[10] P. R. Niven, Balanced Scorecard Step-By-Step, Second., no. June New Jersey: John Wiley \& Sons, Inc., 2006.

[11] S. Schmidt, I. Bateman, J. Breinlinger-O'Reilly, and P. Smith, "A Management Approach that Drives Actions Strategically: Balanced Scorecard in A Mental Health Trust Case Study," Int. J. Health Care Qual. Assur., vol. 19, no. 2, pp. 119-135, 2006, doi: 10.1108/09526860610651663.

[12] R. S. Kaplan and D. P. Norton, Strategy Maps: Converting Intangible Assets Into Tangible Outcomes. Massachusetts: Harvard Business School Publishing Corporation, 2004.

[13] S. Cohen, D. Thiraios, and M. Kandilorou, "Performance parameters interrelations from a balanced scorecard perspective: An analysis of 
Greek companies," Manag. Audit. J., vol. 23, no. 5, pp. 485-503, 2008, doi: $10.1108 / 02686900810875307$.

[14] C. C. Villazón, L. S. Pinilla, J. R. O. Olaso, N. T. Gandarias, and N. L. de Lacalle, "Identification of key performance indicators in project-based organizations through the lean approach," Sustain., vol. 12 , no. 5977, pp. 1-18, 2020, doi: 10.3390/su12155977.

[15] D. Parmenter, Key Performance Indicators: Developing, Implementing, and Using Winning KPIs, Third. New Jersey: John Wiley \& Sons, Inc., 2015.

[16] B. M. Popa, "Challenges When Developing Performance Indicators," J. Def. Resour. Manag., vol. 6, no. 1(10), pp. 111-114, 2015.

[17] H. Kerzner, Project Management Metrics, KPIs, and Dashboards: A Guide to Measuring and Monitoring Project Performance, Third. New Jersey: John Wiley \& Sons, Inc., 2017.

[18] P. Naiyananont and T. Smuthranond, "Relationships between ethical climate, political behavior, ethical leadership, and job satisfaction of operational officers in a wholesale company, Bangkok Metropolitan region," Kasetsart J. Soc. Sci., vol. 38, pp. 345-351, 2017, doi: 10.1016/j.kjss.2016.07.005.

[19] A. Sert, M. Elçi, T. Uslu, and İ. Şener, "The Effects of Organizational Justice and Ethical Climate on Perceived Work Related Stress," Procedia - Soc. Behav. Sci., vol. 150, pp. 11871198, 2014, doi: 10.1016/j.sbspro.2014.09.134.

[20] A. Tziner, M. Felea, and C. Vasiliu, "Relating ethical climate, organizational justice perceptions, and leader-member exchange (LMX) in Romanian organizations," J. Work Organ. Psychol., vol. 31, pp. 51-57, 2015, doi: 10.1016/j.rpto.2015.02.005.

[21] B. Victor and J. B. Cullen, "The Organizational Bases of Ethical Work Climate," Adm. Sci. Q., vol. 33, pp. 101-125, 1988.

[22] M. Yener, M. Yaldiran, and S. Ergun, "The Effect Of Ethical Climate On Work Engagement," Procedia - Soc. Behav. Sci., vol. 58, pp. 724-733, 2012, doi: 10.1016/j.sbspro.2012.09.1050.

[23] A. Newman, H. Round, S. Bhattacharya, and A. Roy, "Ethical Climates in Organizations: A Review and Research Agenda," Bus. Ethics Q., vol. 4, no. October, pp. 475-512, 2017, doi: 10.1017/beq.2017.23.

[24] J. E. Doerr, Measure What Matters: How Google, Bono, and the Gates Foundation Rock the World with OKRs. New York: Penguin Random House LLC, 2018.

[25] D. Wilsey, "Using OKRs with Balanced Scorecard," North Carolina, 2019. [Online]. Available: https://balancedscorecard.org/wpcontent/uploads/2019/08/BSI-Using-OKRs-with-BalancedScorecard.pdf.

[26] X. Islami, E. Mulolli, and N. Mustafa, "Using Management by Objectives as a performance appraisal tool for employee satisfaction," Futur. Bus. J., vol. 4, pp. 94-108, 2018, doi: 10.1016/j.fbj.2018.01.001.

[27] R. L. Mathis and J. H. Jackson, Human Resource Management, Twelfth. Mason: Thomson Corporation, 2008.

[28] T. Donaldson and L. E. Preston, "The Stakeholder Theor of the Corporation: Concepts, Evidence, and Implications," Acad. Manag. Rev., vol. 20, no. 1, pp. 65-91, 1995, doi: 10.5465/amr.1995.9503271992.

[29] M. Minoja, "Stakeholder Management Theory, Firm Strategy, and Ambidexterity," J. Bus. Ethics, vol. 109, no. 1, pp. 67-82, 2012, doi: 10.1007/s10551-012-1380-9.

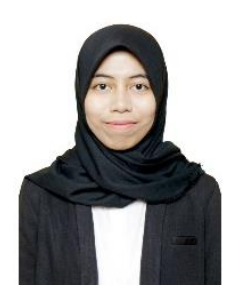

Sarifah U. Sahubawa was born in Ambon, Indonesia on January $15^{\text {th }}$, 1997. She was graduated from Metallurgical Engineering at Bandung Institute of Technology in 2019, and currently she is pursuing Master of Business Administration at Bandung Institute of Technology, focusing on Human Capital Management.

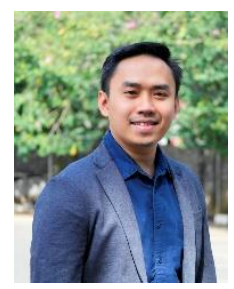

Andika P. Pratama is an Assistant Professor at the School of Business and Management, Bandung Institute of Technology. He received his Ph.D. in Management from Rutgers, the State of New Jersey, in the USA in 2015. His research interests include areas within and across organizational behavior, organization theory, cross-cultural management, and business ethics. 